\title{
Aplikasi Stemming Kata Bahasa Lampung Dialek Api Menggunakan Pendekatan Brute-Force dan Pemograman C\#
}

\author{
Zaenal Abidin', Aldi Wijaya ${ }^{2, *}$, Donaya Pasha ${ }^{3}$ \\ ${ }^{1}$ Fakultas Teknik dan Ilmu Komputer, Prodi Sistem Informasi, Universitas Teknokrat Indonesia, Bandarlampung, Indonesia \\ ${ }^{2}$ Fakultas Teknik dan Ilmu Komputer, Prodi Informatika, Universitas Teknokrat Indonesia, Bandarlampung, Indonesia \\ ${ }^{3}$ Fakultas Teknik dan Ilmu Komputer, Prodi Teknologi Informasi, Universitas Teknokrat Indonesia, Bandarlampung, \\ Indonesia \\ Email: ${ }^{1}$ zabin@ $@$ teknokrat.ac.id, 2,*aldiwijayaittkj69@gmail.com, ${ }^{3}$ donayapasha@gmail.com \\ Email Penulis Korespondensi: aldiwijayaittkj69@gmail.com
}

\begin{abstract}
Abstrak-Lampung adalah salah satu daerah di pulau Sumatera yang memiliki bahasa daerah dan aksara Lampung. Di provinsi ini terdapat dua dialek bahasa daerah utama yaitu dialek api dan dialek nyo. Upaya penelitian untuk pelestarian bahasa Lampung secara digital telah dilakukan oleh para peneliti dari berbagai Universitas. Penelitian stemming kata bahasa Lampung dialek api didasari oleh temuan fakta bahwa mesin penerjemah bahasa Lampung dialek api berbasis kamus tidak dapat menerjemahkan kata-kata yang berimbuhan. Stemming kata bahasa Lampung dialek api dilakukan dengan pendekatan Bruteforce. Dalam bahasa Lampung terdapat verba infleksional dan verba derivasional. Verba infleksional adalah verba bentukan dari dasar yang juga berkategori verba sedangkan verba derivasional adalah verba bentukan dari dasar yang berkategori selain verba seperti nomina, adjektiva, adverbia, pronomina dan numeralia. Tujuan penelitian ini adalah (1) melakukan stemming kata dengan pendekatan Brute-force, (2) menghasilkan aplikasi sebagai Stemmer kata bahasa Lampung dialek api menggunakan bahasa pemograman C\# dan basis data secara online menggunakan Firebase. Metode yang digunakan pada penelitian ini terdiri dari (1) Peneliti mencari, mengidentifikasi, mendata, mengetikkan secara manual 2000 kata berimbuhan berikut kata dasar bahasa Lampung dialek api, (2) membuat algoritma stemming dengan pendekatan Brute-force (3) menguji coba aplikasi yang telah dibuat. Adapun hasil yang didapat adalah aplikasi mampu melakukan stemming kata untuk kata-kata yang telah teridentifikasi pada 2000 kata berimbuhan dan jika tidak dapat dilakukan stemming maka disediakan fasilitas untuk memperbaharui basis data yang digunakan dalam aplikasi agar dapat digunakan untuk stemming karena aplikasi stemming sangat menunjang pada aplikasi mesin penerjemah berbasis kamus. Urgensi penelitian aplikasi Stemming adalah untuk mengatasi kata berimbuhan pada aplikasi mesin penerjemah mesin penerjemah bahasa Lampung dialek api berbasis kamus untuk penelitian selanjutnya.
\end{abstract}

Kata Kunci: Bahasa Lampung; Dialek Api; Stemming; Pemograman C\#; Firebase

Abstract-Lampung is one of the areas on the island of Sumatra that has the regional language and script of Lampung. In this province there are two main regional dialects, namely the dialect of fapi and the dialect of nyo. Research efforts for the preservation of the Lampung language digitally have been conducted by researchers from various Universities. The research stemming from Lampung dialects of api is based on the findings of the fact that the dictionary-based Lampung dialects of the Lampung language dialect cannot translate the affix words. Stemming of Lampung language dialects of api is worked with a Brute-force approach. In the Lampung language there are inflexional verbs and derivational verbs. Inflexional verbs are verbs formed from bases that are also categorized verbs while derivational verbs are verbs formed from bases that are categorized in addition to verbs such as nouns, adjectives, adverbs, pronouns and numerals. The purpose of this research is to (1) conduct word stemming with a Brute-force approach, (2) produce an application as a Lampung language word Stemmer dialect of api using C \# programming language and online database using Firebase. The methods used in this study consisted of (1) Researchers are looking for, identifying, recording, manually typing 2000 words following the basic words of the Lampung dialect of api, (2) creating a stemming algorithm with a Brute-force approach (3) testing applications that have made. As for the result obtained is the application is able to do word stemming for words that have been identified in 2000 words and if stemming can not be done then the facility is provided to update the database used in the application to be used for stemming because the stemming application is very supportive of the application dictionary-based translation engine. The urgency of Stemming application research is to address the affix word in the Lampung language machine translation machine translation application for further research.

Keywords: Lampung Languge; Dialect of Api; Stemming; C\# Programming; Firebase

\section{PENDAHULUAN}

Provinsi Lampung adalah salah satu provinsi di pulau Sumatera yang memiliki kebudayaan yang unik berupa bahasa daerah Lampung dan tulisan aksara Lampung. Di provinsi Lampung terdapat dua dialek bahasa daerah yang utama yaitu dialek api dan dialek nyo. Pemerintah daerah provinsi Lampung terus berupaya untuk mencegah kepunahan bahasa Lampung ini sesuai dengan Undang-undang Republik Indonesia Nomor 24 Tahun 2009. Adanya Peraturan Daerah Nomor 8 Tahun 2008 dan Peraturan daerah tersebut diperkuat lagi oleh Peraturan Gubernur Lampung No. 4 Tahun 2011 menunjukkan bahwa Pemerintah Daerah provinsi Lampung ikut menjaga pemertahanan bahasa Lampung [1]. Selain pemerintah daerah, upaya mencegah kepunahan bahasa Lampung dapat dilakukan oleh para peneliti di bidang komputer khususnya di berbagai Universitas atau perguruan tinggi di provinsi Lampung sebagai wujud keperdulian pada pelestarian bahasa daerah. Upaya penelitian untuk pelestarian bahasa Lampung secara komputasi atau digital telah dan sedang terus dilakukan oleh para peneliti di Universitas di provinsi Lampung seperti dari Universitas Teknokrat Indonesia dan Universitas Lampung. Penelitian yang 
menggunakan objek bahasa Lampung dari sisi komputasi belum banyak dijumpai khususnya di bidang pemrosesan bahasa alami bahasa Lampung seperti mesin penerjemah bahasa Lampung, pemrosesan suara bahasa Lampung.

Penelitian stemming kata bahasa Lampung dialek api didasari oleh temuan fakta bahwa mesin penerjemah bahasa Lampung dialek api berbasis kamus tidak dapat menerjemahkan kata-kata yang berimbuhan. Penelitian ini dilakukan khusus untuk mencoba membangun aplikasi stemming kata berimbuhan bahasa Lampung dialek api dengan pendekatan Brute-force, dimana aplikasi dibuat secara terpisah dari aplikasi mesin penerjemah kalimat bahasa Lampung dialek api. Penelitian juga guna memahami karakteristik kata berimbuhan pada bahasa Lampung dialek api. Penelitian mesin penerjemah bahasa Lampung tersebut telah dilakukan dan makalah penelitian telah dipersentasikan di Seminar Leksikografi 2019 yang diadakan oleh kantor pusat badan bahasa di DKI Jakarta [2]. Dalam bahasa Lampung terdapat verba infleksional dan verba derivasional [3]. Verba infleksional adalah verba bentukan dari dasar yang juga berkategori verba sedangkan verba derivasional adalah verba bentukan dari dasar yang berkategori selain verba seperti nomina, adjektiva, adverbia, pronomina dan numeralia. Verba infleksional sangat prodiktif pada bahasa Lampung dan ditemukan pada seluruh verba berprefiks $\{\mathrm{N}-\}[1]$. Penelitian stemming kata telah dilakukan di berbagai bahasa seperti pada penelitian kata pada bahasa Madura [4]. Pada penelitian stemming di bahasa Madura menggunakan algoritma Enhanced Confix Stripping Stemmer (ECS), penelitian stemming pada bahasa Sunda menggunakan pendekatan berbasis aturan [5], pada stemming kata bahasa Indonesia telah banyak dilakukan oleh para peneliti dari Universitas Indonesia [6] dan [7], stemming bahasa Indonesia peneliti dari STMIK Sinar Nusantara Surakarta menggunakan perbandingan dua algoritma stemming [8] dan penelitian stemming dari Univeristas Jendral Soedirman menggunakan pendekatan algoritma Porter dan menggunakan website untuk implementasinya [9], pada penelitian stemming pada bahasa Inggris menggunakan algoritma Paice/Husk [10], pada penelitian stemming dokumen bahasa Sunda berbasis kamus [11].

Stemming sangat bermanfaat dalam pemrosesan bahasa alami seperti pada masalah temu kembali informasi, mesin penerjemah, klasifikasi teks, peringkasan teks. Penelitian terkait dengan mesin penerjemah pada bahasa Lampung ke bahasa Indonesia dengan pendekatan jaringan syaraf tiruan telah dilakukan pada tahun 2017, yaitu neural machine translation (NMT) tanpa mekanisme attention [12] dan yaitu neural machine translation (NMT) dengan mekanisme attention[13]. Baik pada penelitian NMT yang menggunakan mekanisme attention atau tanpa attention keduanya masih berpotensi digali kembali ketika menghadapi masalah penerjemahan kata berimbuhan. Untuk penelitian terkait dengan mesin penerjemah pada bahasa Lampung ke bahasa Indonesia dengan pendekatan statistical machine translation (SMT) telah dilakukan pada tahun 2020 [14]. Pada penelitian SMT bahasa Lampung ke Indonesia masih memiliki kendala ketika menemui kata-kata yang mengandung kata berimbuhan, seperti yang dilakukan pada penelitian SMT bahasa Sunda [5].

Tujuan penelitian ini adalah (1) melakukan stemming kata dengan pendekatan Brute-force, (2) menghasilkan aplikasi sebagai Stemmer kata bahasa Lampung dialek api menggunakan bahasa pemograman C\# dan basis data secara online menggunakan Firebase. Metode yang digunakan pada penelitian ini terdiri dari (1) Peneliti mencari, mengidentifikasi, mendata, mengetikkan secara manual 2000 kata berimbuhan berikut kata dasar bahasa Lampung dialek api, (2) membuat algoritma stemming dengan pendekatan Brute-force (3) menguji coba aplikasi yang telah dibuat. Urgensi dari hasil penelitian stemming kata bahasa Lampung dialek api adalah sebagai solusi untuk aplikasi mesin penerjemah kalimat bahasa Lampung dialek api pada penelitian selanjutnya. Perwujudan dari penelitian ini adalah terwujudnya aplikasi stemmer atau program komputer pengubah suatu kata menjadi kata dasarnya khusus untuk kata bahasa Lampung dialek api sebagai alat bantu mesin penerjemah kalimat dalam bahasa Lampung khususnya dan juga untuk riset Natural Language Processing pada bahasa Lampung secara umum. Urgensi lainnya adalah menggali potensi riset lainnya pada Natural Language Processing bahasa Lampung. Hasil penelitian diharapkan mampu membuka peluang bagi penelitian Natural Language Processing bagi bahasa daerah Lampung dan bahasa daerah lainnya sebagai upaya pelestarian bahasa daerah secara digital.

\section{METODOLOGI PENELITIAN}

Metode dalam penelitian ini terdiri dari tiga tahapan yaitu: (1) Peneliti mencari, mengidentifikasi, mendata, mengetikkan secara manual 2000 kata berimbuhan berikut kata dasar bahasa Lampung dialek api, (2) membuat algoritma stemming dengan pendekatan Brute-force (3) menguji coba aplikasi yang telah dibuat. Tahapan penelitian ditunjukan pada gambar 1 di bawah ini.

\subsection{Pencarian, Pengidentifikasi, Pendataan dan Pengetikan Kata Berimbuhan dan Kata Dasarnya}

Data yang disiapkan untuk penelitian stemming kata bahasa Lampung dialek api terdiri dari (a) Data set, yakni data berupa kata dari bahasa Lampung dialek api yang berbentuk kata berimbuhan baik awalan, akhiran, awalanakhiran, sisipan. Peneliti berupaya mengidentifkasi kata-kata dalam bahasa Lampung dialek api. Data set akan digunakan untuk basis data aplikasi stemming yang akan dibuat menggunakan bahasa pemograman C\#. Data set ini berasal dari kosa kata berimbuhan dalam bahasa Lampung dialek api yang diambil dan diketik secara manual dari buku ajar SD, SMP serta dari buku Morfologi bahasa Lampung [3] dan buku Afiksasi bahasa Lampung [15]. Hasil pencaraian yang telah dilakukan oleh peneliti adalah berupa 2000 kata, beragam variasi kata berimbuhan 


\section{JURNAL MEDIA INFORMATIKA BUDIDARMA}

Volume 5, Nomor 1, Januari 2021, Page 1-8

ISSN 2614-5278 (media cetak), ISSN 2548-8368 (media online)

Available Online at https://ejurnal.stmik-budidarma.ac.id/index.php/mib DOI 10.30865/mib.v5i1.2483

yang berhasil didapatkan. (b) Data uji, yakni kumpulan kata yang diambil secara sembarang dari penutur asli bahasa Lampung dialek api.

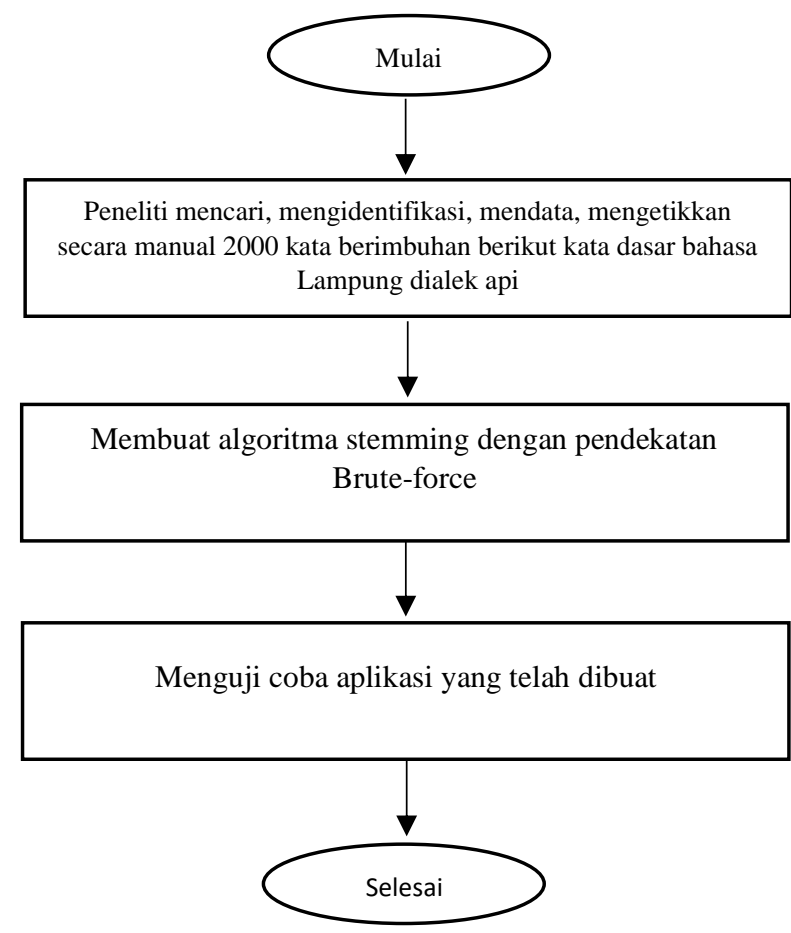

Gambar 1. Tahapan penelitian stemming kata bahasa Lampung dialek api

Tabel 1 di bawah ini, menginfomasikan sampel dari 2000 kata berimbuhan dalam bahasa Lampung dialek api yang berhasil didapatkan dari sumber buku ajar SD, SMP serta dari buku Morfologi bahasa Lampung [3] dan buku Afiksasi bahasa Lampung [15]. Adapun detail 2000 kata tersebut dapat dilihat pada tautan yang disediakan berikut ini https://drive.google.com/file/d/1VzzGfrUkD0MWs7nbAOy_tD9eWDPiQt5j/view?usp=sharing.

Tabel 1. Contoh kata berimbuhan dalam bahasa Lampung dialek api

\begin{tabular}{lll}
\hline \multicolumn{1}{c}{ Bahasa Lampung } & \multicolumn{1}{c}{$\begin{array}{c}\text { Kata } \\
\text { Dasar }\end{array}$} & $\begin{array}{l}\text { Arti Dalam } \\
\text { Bahasa Indonesia }\end{array}$ \\
\hline abaiko & abai & abaikan \\
abangku & abang & abang saya \\
babalakan & balak & Besar-besaran \\
babangikan & bangik & Enak-enakan \\
babuini & babui & babi nya \\
buwakni & buwak & kueh nya \\
buwokni & buwok & rambutnya \\
cabikmu & cabik & cabai kamu \\
cabikni & cabik & cabai nya \\
numbak & tumbak & menombak \\
nunjukko & tunjuk & menunjukkan \\
Nuntong & tuntong & menatap \\
nutu & tutu & menumbuk \\
tupingni & tuping & topengnya \\
minok & hinok & menginap \\
\hline
\end{tabular}

\subsection{Algoritma Brute-Force untuk Aplikasi Stemming Kata Bahasa Lampung Dialek Api}

Tahapan ini merupakan inti dari penelitian ini, yakni tahap pembuatan algoritma Brute-Force untuk stemming bahasa Lampung dialek api. Ide dasar dari algoritma Brute-Force adalah membuat tabel look up antara daftar kata yang akan dilakukan stemming dan hasil stemming-nya [16]. Program komputer diharapkan mampu melakukan pengecekan antara kata yang akan di-stemming dengan ketersediaan pada tabel lookup. Algoritma Brute-force disajikan dalam bentuk flow chart di gambar 2 di bawah ini. 


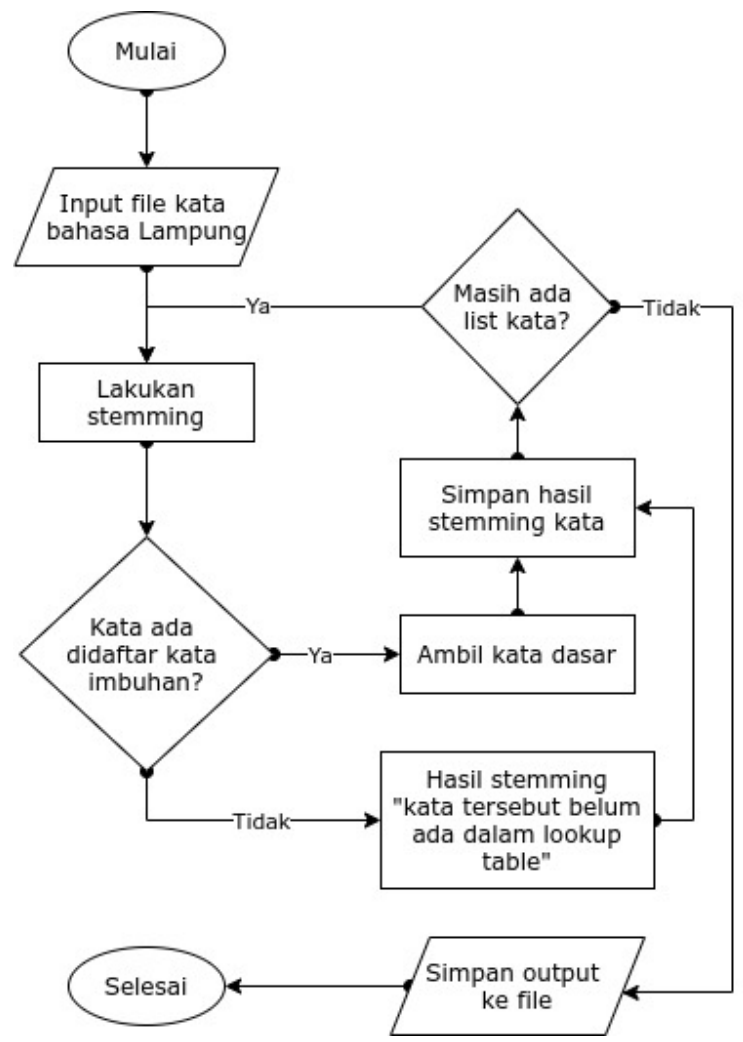

Gambar 2. Flow Chart Algoritma Brute-Force Pada Stemming

Algoritma Brute-force yang dibangun untuk stemming kata bahasa Lampung dialek api menggunakan daftar 2000 kata berimbuhan dan kata dasarnya dalam bahasa Lampung dialek api sebagai bahan untuk mengisi tabel look up. Tahapan algorima Brute-force dimulai dari saat user memasukan satu buah kata yang akan diujicoba untuk dicari kata dasarnya. Kata yang dimasukan pada program akan diproses, (1) dengan cara mengubah kata masukan menjadi bentuk kata yang sudah berada dalam kondisi huruf kecil, kemudian (2) kata yang dimasukan akan dilakukan pencocokan satu satu terhadap 2000 kata berimbuhan yang disediakan. Jika ditemukan maka aplikasi akan mengambil kata dasarnya dari basis data aplikasi kemudian menampilkan hasil berupa kata dasar dari kata berimbuhan, namun jika tidak ditemukan maka aplikasi akan menampilkan 'kata tersebut belum ada di dalam tabel look up'. Dengan cara yang sama seperti disebutkan di atas, begitupun hal yang sama akan dilakukan jika user memasukan lebih dari satu kata yang akan diujicoba untuk dicari kata dasarnya.

\subsection{Pengujian Aplikasi Stemming Kata Bahasa Lampung Dialek Api}

Pada tahapan ini dilakukan pengujian terhadap algoritma yang dikembangkan pada tahap sebelumnya, pengujian dilakukan dengan menggunakan data set yang sudah disiapkan pada tahap pertama. Pengujian dilakukan dengan menggunakan sampel sebagai perwakilan dari 2000 data set.

\section{HASIL DAN PEMBAHASAN}

Pada bagian ini berisi hasil dan pembahasan dari penelitian stemming kata pada bahasa Lampung api. Dua hal utama yang disajikan adalah bukti hasil implementasi dan bukti hasil pengujian.

\subsection{Implementasi Aplikasi Stemming dengan Pendekatan Brute-force dan Pemograman C\#}

Pada bagian ini berisi hasil implementasi dari aplikasi stemming kata bahasa Lampung dialek api. Peneliti menggunakan bahasa pemograman C\# dalam mengimplementasikan aplikasi stemming dengan Brute-force. Pada saat pertama kali aplikasi stemming kata bahasa Lampung dialek api dijalankan akan tampil interface seperti pada gambar 3 di bawah ini. Pada gambar 3 di bawah ini adalah tampilan pertama pada saat kita menjalankan programnya. Terdapat 1 tombol / Button pada saat awal program di jalankan yaitu Button Login. Adapun fungsi dari tombol tersebut adalah (1) disini digunakan untuk user (pengguna) atau admin melakukan kegiatan awal masuk ke aplikasi untuk proses stemming kata bahasa lampung dialek api. Khusus untuk admin untuk melakukan proses penambahan kata di basis data aplikasi ataupun menghapus/mengedit kata - kata yang ada di dalam basis data tetap melalui Button Login. 


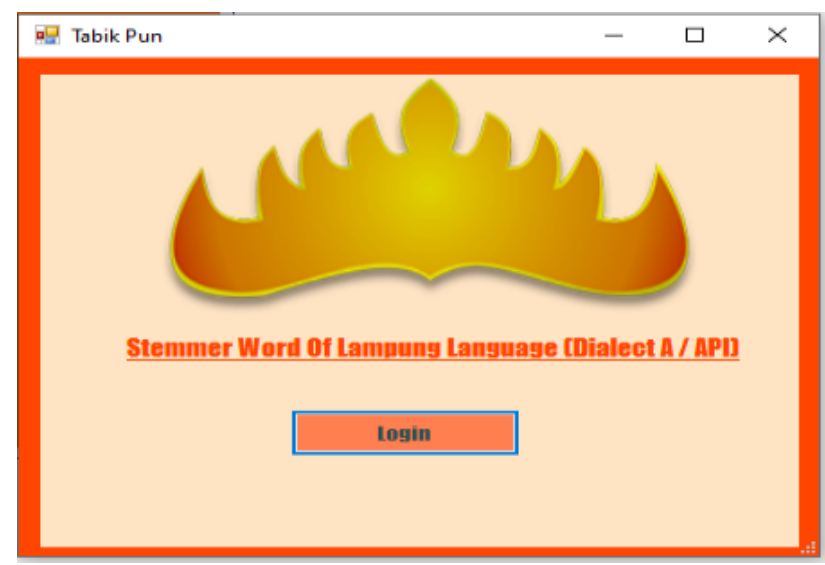

Gambar 3. Tampilan Awal Program dijalankan

Ketika button Login ditekan maka akan menampilkan interface seperti terlihat di gambar 4 di bawah ini. Pada gambar 4 di bawah, peneliti membuat interface sesederhana mungkin dengan harapan mempermudah pengguna dalam menjalankan aplikasi stemming kata bahasa Lampung dialek api. Fungsi utama dari aplikasi ini adalah sebagai pendukung utama pada aplikasi mesin penerjemah yang kelak berpotensi dibangun menggunakan bahasa pemograman $\mathrm{C \#}$.

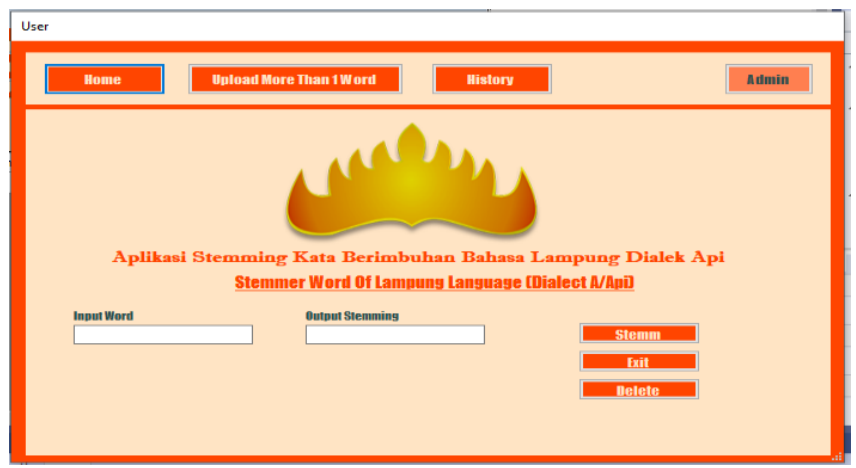

Gambar 4. Tampilan Form User dan Admin

Pada di tampilan form user terdapat beberapa button diantaranya (1) Button Home fungsinya untuk menampilkan tampilan awal pada saat masuk tampilan user, (2) Button Upload More Than 1 Word fungsinya untuk melakukan stemming melalui pembacaan file dibuat dengan format ekstensi .txt melalui notepad, hal ini berguna ketika pengguna ingin melakukan stemming lebih dari 1 kata bahasa Lampung dialek api, (3) Button History fungsinya untuk melihat kata - kata yang telah dimasukan oleh user di aplikasi ini, (4) Button Stemm fungsinya untuk dilakukan proses stemming kata yang memiliki imbuhan kemudian diubah menjadi kata dasarnya, khusus tombol stemm ketika ditekan maka akan menjalankan listing program Brute-force, (5) Button Delete fungsinya untuk menghapus kata atau teks yang ada pada textbox sehingga menjadi kosong kembali seperti sedia kala, (6) Button Exit fungsinya untuk keluar dari tampilan user dan kembali ke tampilan awal program, (7) Button Admin fungsinya untuk bagian admin yang mengelola aplikasi ini dalam hal menambah, menghapus basis data pada aplikasi ini.

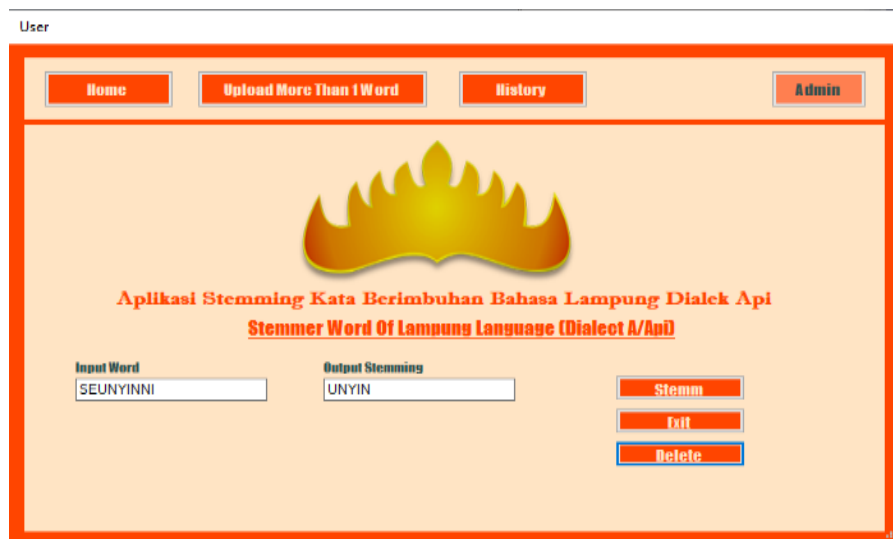

Gambar 5. Tampilan Uji Coba Stemming 
Pada gambar 5 di atas ditunjukan sebuah contoh ketika user ingin mencoba melakukan stemming sebuah kata dari bahasa Lampung dialek api yaitu kata "SEUNYINNI". User memasukan kata tersebut di textbox yang disediakan di bagian Input Word dan ketika user menekan tombol Stemm maka aplikasi akan memberikan hasil "unyin" seperti yang tertera di gambar 5 di atas. Apapun kata bahasa Lampung yang dimasukan dalam textbox yang disediakan di bagian Input Word baik berupa huruf besar atau kecil atau gabungan keduanya maka tidak menimbulkan masalah apapun. Kecuali kata berimbuhan yang dimasukan dalam textbox yang disediakan di bagian Input Word tidak tersedia di basis data yang dimiliki aplikasi maka akan muncul pesan kata yang dimasukan tidak dapat di-stemm.

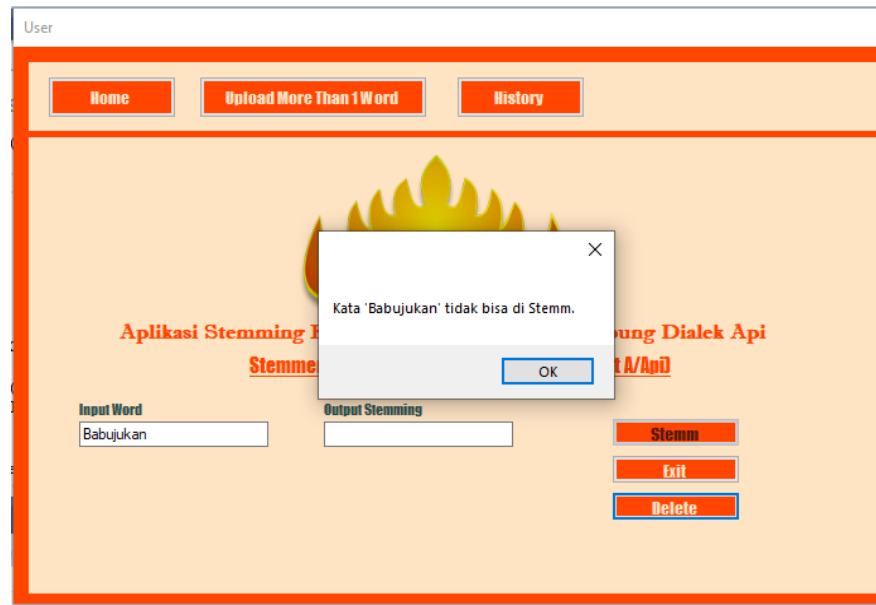

Gambar 6. Contoh Tampilan Kata yang Tidak Bisa Dilakukan Stemming

Gambar 6 adalah contoh kata yang tidak berhasil dapat di-stemming. Solusi yang dapat dilakukan jika menemui hal ini adalah admin dapat memperbaharui tabel lookup yang telah dibuat. Jika telah diperbaharui maka aplikasi ini akan mampu melakukan stemming pada kata "Babujukan".

Seperti ditunjukan pada gambar 5, jika user ingin mencoba melakukan stemming lebih dari 1 kata maka user harus menekan tombol Upload More Than 1 Word. Hasil dari menekan tombol Upload More Than 1 Word ditunjukan pada gambar 7 di bawah ini. Satu hal utama yang harus dilakukan user adalah membuat sebuah file dengan ekstensi *txt dengan aplikasi notepad. File berekstensi *txt tersebut akan digunakan saat user menekan tombol upload, kemudian hasil stemming akan diberikan seperti tergambar pada gambar 8 di bawah ini. Button upload yang digunakan untuk mengunggah file yang akan melakukan proses stemming. Bagian ini sangat penting ketika user ingin melakukan stemming kata lebih dari satu kata. Pada gambar 3 di atas terlihat masih kosong karena belum pernah di lakukan upload file untuk stemming. Berikut gambar 4 di bawah ini yang akan menampilkan proses stemming file, tetapi sebelumnya dibuat file data, yang akan dilakukan stemming, di notepad berekstensi .txt terlebih dahulu, kemudian setelah itu file data itu dapat diproses untuk stemming.

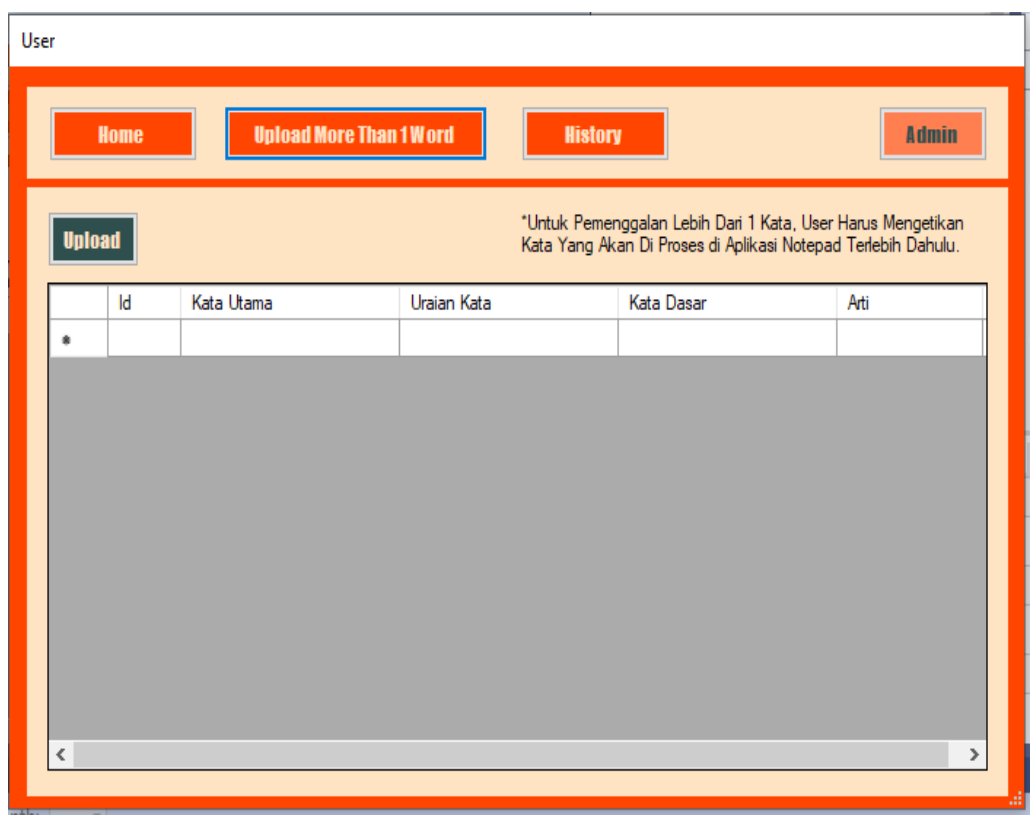

Gambar 7. Tampilan Ketika User Ingin Melakukan Stemming Lebih dari 1 Kata 


\begin{tabular}{|l|l|l|l|l|l|}
\hline & Id & Kata Utama & Uraian Kata & Kata Dasar & Arti \\
\hline & $15977 \ldots$ & waghungni & waghung+ni & waghung & warung nya \\
\hline & $15977 \ldots$ & abaiko & abai+ko & abai & abaikan \\
\hline & $15977 \ldots$ & bebaini & bebai+ni & bebai & istri nya \\
\hline & $15977 \ldots$ & nyebeghang & N + sebeghang & sebeghang & menyeberang \\
\hline & $15977 \ldots$ & sekulani & sekula+ni & sekula & sekolahnya \\
\hline & $20081 \ldots$ & abangni & abang +ni & abang & kakak laki - laki \\
\hline & $20081 \ldots$ & lapahan & lapah + an & lapah & berjalan \\
\hline & $20082 \ldots$ & nginm & & kinm & \\
\hline & nyeghitako & - & - & - \\
\hline & nyelesaiko & - & - & - \\
\hline & & nyembah & - & & \\
\hline
\end{tabular}

Gambar 8. Tampilan Hasil Upload dan Telah Diproses

Gambar 8 menyajikan informasi bahwa user telah mengunggah file berekstensi .txt yang berisi 11 kata berbahasa Lampung dialek api yaitu waghungni, abaiko, bebaini, nyebeghang, sekulani, abangni, lapahan, ngirim, nyeghitako, nyelesaiko dan nyembah. Aplikasi stemming bahasa Lampung dialek api akan memproses 11 kata tersebut satu persatu. Dimulai dari kata waghungni, kata tersebut akan dilakukan pencocokan satu persatu pada basis data di aplikasi ini. Gambar 8 menunjukan kata waghungni ditemukan dalam basis data sehingga aplikasi memberikan hasil terutama kata dasarnya yaitu waghung. Selanjutnya kata abaiko, kata akan tersebut dilakukan pencocokan satu persatu pada basis data di aplikasi ini. Gambar 8 menunjukan kata abaiko ditemukan dalam basis data sehingga aplikasi memberikan hasil terutama kata dasarnya yaitu abai. Hal yang sama dilakukan pada kata bebaini, nyebeghang, sekulani, abangni, lapahan. Setelah dilakukan proses stemming menggunakan aplikasi ini, seperti terlihat pada gambar $8 \mathrm{di}$ atas, hasil menunjukan kata waghungni, abaiko, bebaini, nyebeghang, sekulani, abangni, lapahan, ngirim berhasil di-stemming dan diperoleh kata dasarnya. Sedangkan kata nyeghitako, nyelesaiko dan nyembah yang berada di tiga kata terakhir tidak berhasil di-stemming. Hal ini menunjukan ketiga kata tersebut tidak dalam basis data aplikasi yang telah dibuat.

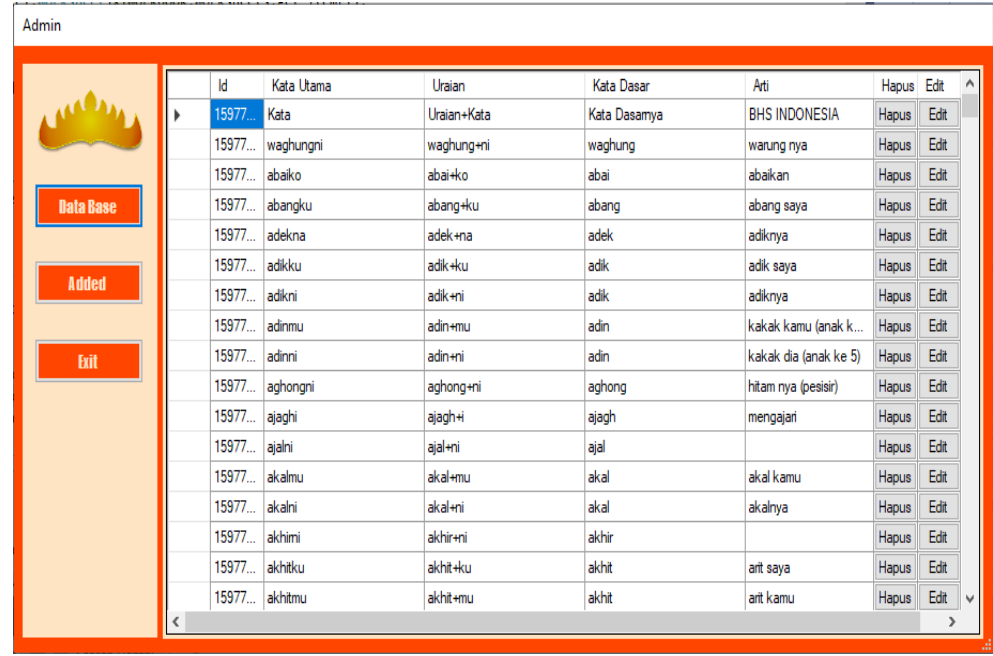

Gambar 9. Tampilan Interface dari Halaman Admin

Sesuai gambar 6, jika user menekan tombol admin maka akan muncul seperti di gambar 9 di atas. Setelah kita berhasil login, maka selanjutnya akan melihat basis data dari 2000 yang digunakan pad aplikasi stemming kata bahasa Lampung dialek api. Gambar menunjukan basis data yang merupakan tampilan basis data yang telah terkoneksi dengan Firebase melalalui sambungan koneksi intenet. Di dalam form admin ini kita dapat menambahkan kata baru ataupun menghapus kata yang sudah ada di dalam basis data. Gambar 9 di atas ini menampilkan basis data yang ada pada firebase. Keunggulan dari firebase yaitu menampilkan data secara realtime,sehingga memudahkan kapan dan dimana pun dapat mengaksesnya melalui laptop atau pc mana saja asalkan ada koneksi internet.

\section{KESIMPULAN}

Penelitian stemming kata bahasa Lampung dialek api dengan pendekatan Brute-force dengan menggunakan 2000 kata berimbuhan berikut kata dasarnya dengan bahasa Pemograman C\# berhasil dibuat. Penelitian ini sangat penting dilakukan guna memperbaiki mesin penerjemah bahasa Lampung berbasis kamus ketika menemui kata 
yang tidak ada di dalam basis data aplikasi tersebut. Pendekatan Brute-force pada stemming kata bahasa Lampung, pada hakikatnya adalah pencocokan kata yang di-input dengan ketersedian kata yang ada dalam basis data kata berimbuhan. Pendekatan ini tentu memiliki kekurangan jika kata berimbuhan tidak ada di luar 2000 kata berimbuhan berikut kata dasarnya. Hasil penelitian ini akan digunakan untuk membangun mesin penerjemah kalimat bahasa Lampung dialek api yang mampu mengatasi kata berimbuhan. Penelitian stemming kata bahasa Lampung dialek api selanjutnya dapat dilakukan dengan menggunakan pendekatan metode Affix Removal Algorithm, Analisis morfologi kata, pendekatan secara Statistika dll seperti tertera pada artikel [16].

\section{UCAPAN TERIMAKASIH}

Penulis mengucapkan terima kasih kepada Kementrian Riset dan Teknologi / Badan Riset dan Inovasi Nasional yang telah memberi dukungan financial terhadap penelitian ini melalui skema Penelitian Dosen Pemula (PDP) tahun 2020 dengan nomor kontrak 078/SP2H/LT/DRPM/2020, 839/SP2H/LT/MONO/LL2/2020, 023/UTI/LPPM/E.1.3/VII/2020. Penulis juga mengucapkan terima kasih kepada Lembaga Penelitian dan Pengabdian Masyrakat Universitas Teknokrat Indonesia yang telah memberikan arahan bagi dosen pemula dalam melaksanakan skema hibah Penelitian Dosen Pemula (PDP) dan Rektor Universitas Teknokrat Indonesia yang telah memberikan arahan, motivasi dan semangat bagi dosen pemula untuk terus belajar dan meneliti sampai memperoleh tahapan jenjang akademis tertinggi.

\section{REFERENCES}

[1] F. Ariyani, "Distribusi Verba Berfrefiks (N-) Pada Bahasa Lampung dalam Kitab Kuntara Raja Niti dan Buku Ajar. Ranah: Jurnal Kajian Bahasa 3," Ranah J. Kaji. Bhs., vol. 3, no. 2, pp. 124-134, 2014, doi: https://doi.org/10.26499/rnh.v3i2.43.

[2] J. Fakhrurozi, Z. Abidin, and F. Ariyani, "Purwarupa Aplikasi Mesin Penerjemah Bahasa Lampung Dialek Api berbasis Kamus Bahasa Lampung Menggunakan Bahasa Pemograman Python Prototype of Application Machine Translation Lampung Language Sentence of Api Dialect Dictionary Based Using Python Programmin.'

[3] F. Ariyani, Pengantar morfologi Bahasa Lampung kajian teoretis dan praktis. Yogyakarta: Textium, 2017.

[4] R. Maulidi, "Modifikasi Metode Enhanced Confix Stripping," Pros. Semin. Nas. FDI 2016, no. December, pp. 12-15, 2016.

[5] A. Ardiyanti Suryani, D. Hendratmo Widyantoro, A. Purwarianti, and Y. Sudaryat, "The rule-based sundanese stemmer," ACM Trans. Asian Low-Resource Lang. Inf. Process., vol. 17, no. 4, 2018, doi: 10.1145/3195634.

[6] M. Adriani, J. Asian, B. Nazief, S. M. M. Tahaghoghi, and H. E. Williams, "Stemming Indonesian: A confix-stripping approach," ACM Trans. Asian Lang. Inf. Process., vol. 6, no. 4, 2007, doi: 10.1145/1316457.1316459.

[7] J. Asian, H. E. Williams, and S. M. M. Tahaghoghi, "Stemming Indonesian," Conf. Res. Pract. Inf. Technol. Ser., vol 38, no. 4, pp. 307-314, 2005, doi: 10.1145/1316457.1316459.

[8] D. Wahyudi, T. Susyanto, and D. Nugroho, "Implementasi Dan Analisis Algoritma Stemming Nazief \& Adriani Dan Porter Pada Dokumen Berbahasa Indonesia," J. Ilm. SINUS, vol. 15, no. 2, pp. 49-56, 2017, doi: 10.30646/sinus.v15i2.305.

[9] L. Afuan, "Stemming Dokumen Teks Bahasa Indonesia Menggunakan Algoritma Porter," Telematika, vol. 6, no. 2, pp. $34-40,2013$

[10] D. A. A. D. K. Siti Ummi Masruroh, "Penerapan Algoritma Paice atau Husk untuk Stemming pada Kamus Bahasa Inggris ke Bahasa Indonesia," J. Tek. Inform., vol. 6, no. 2, 2013, doi: 10.15408/jti.v6i2.2031.

[11] A. Purwoko and S. Pascasarjana, "Berbasis kamus untuk dokumen berbahasa sunda," 2011.

[12] Z. Abidin, "Penerapan Neural Machine Translation untuk Eksperimen Penerjemahan secara Otomatis pada Bahasa Lampung - Indonesia," Pros. Semin. Nas. Metod. Kuantitatif 2017, no. 978, pp. 53-68, 2017.

[13] Z. Abidin, A. Sucipto, and A. Budiman, "Penerjemahan Kalimat Bahasa Lampung-Indonesia Dengan Pendekatan Neural Machine Translation Berbasis Attention Translation of Sentence Lampung-Indonesian Languages With Neural Machine Translation Attention Based," J. Kelitbangan, vol. 06, no. 02, pp. 191-206, 2018.

[14] P. Permata and Z. Abidin, "Statistical Machine Translation Pada Bahasa Lampung Dialek Api Ke Bahasa Indonesia," Media Inform. Budidarma, vol. 4, no. 3, pp. 519-528, 2020, doi: 10.30865/mib.v4i3.2116.

[15] F. Ariyani, Afiksasi Verba Bahasa Lampung. Yogyakarta: Textium, 2016.

[16] J. Singh and V. Gupta, "Text Stemming," ACM Comput. Surv., vol. 49, no. 3, pp. 1-46, 2016, doi: 10.1145/2975608 